ISSN pr. 2412-608X, ISSN on. 2412-6098

Масличные культуры.

Вып. 2 (182), 2020

УДК 633.853.486:631.52

DOI: $10.25230 / 2412-608 X-2020-2-182-44-50$

Исходный материал для селекции ярового рыжика (Camelina sativa (L.) Crantz) по содержанию масла и белка в семенах в различных эколого-географических условиях

${ }^{\mathbf{1}}$ Н.Г. Конькова,

научный сотрудник

${ }^{1}$ Т.В. Шеленга,

кандидат биологических наук

1Л.Л. Малышев,

кандидат биологических наук

${ }^{2}$ Т.П. Рыбакова,

младший научный сотрудник

${ }^{2}$ М.Ш. Асфандиярова,

кандидат сельскохозяйственных наук

${ }^{1}$ Федеральный исследовательский центр «Всероссийский институт генетических ресурсов растений им. Н.И. Вавилова (ВИР)»

Россия, 190000, Санкт-Петербург, ул. Б. Морская, д. 42

E-mail: ninakonkova.1@mail.ru

${ }^{2}$ ФГБНУ «Прикаспийский аграрный федеральный научный центр Российской академии наук»

416251, Астраханская обл., Черноярский p-н, c. Соленое Займище, Квартал Северный, д. 8.

E-mail:rtuz@yandex.ru

Для цитирования: Конькова Н.Г., Шеленга Т.В., Мальишев Л.Л., Рыбакова Т.П., Асфандиярова М.Ш. Исходный материал для селекции ярового рыжика (Camelina sativa (L.) Crantz) по содержанию масла и белка в семенах в различных экологогеографических условиях // Масличные культуры. 2020. - Вып. 2 (182). - С. 44-50.

Ключевые слова: рыжик, масло, белок, насыщенные жирные кислоты, ненасыщенные жирные кислоты.

Материалом для исследования послужили 315 образцов рыжика (Camelina sativa (L.) Crantz) из коллекции Всероссийского института генетических ресурсов растений (ВИР). Исследование проводилось в течение трех лет в четырех различных эколого-географических пунктах. В среднем за три года во всех точках исследования содержание масла колебалось от 33,0 до $37,4 \%$, белка - от 24,7 до 29,7 \%. Больше масла накапливалось в условиях Северо-Западного региона - 37,1 \% и
Тамбовской области - 36,5 \%. Содержание белка в Краснодарском крае и в Астраханской области было практически идентично и составило 28,6 и 28,4 \%. Корреляционный анализ показал обратную зависимость содержания белка и масла в семенах. Коэффициенты корреляции варьировали от $r=-0,40$ до $r=-0,76$. Образцы из Северной Европы содержали наибольший процент масла (37,5\%), наибольшее количество белка наблюдалось в образцах сибирского происхождения (27,8 \%). Анализ влияния температурных условий и количества осадков на содержание масла и белка в семенах рыжика показал относительную независимость данных признаков от условий среды. Изменчивость образцов по величине коэффициента регрессии содержания масла и белка от суммы температур составляет 45,8 и 46,6 \% соответственно, от суммы осадков - 128,9 и 184,3\%, что свидетельствует о разнообразной реакции образцов на условия среды.

\section{UDC 633.853.486:631.52}

Germplasm material for spring false flax (Camelina sativa (L.) Crantz) breeding on the oil and protein contents in different ecological and geographical environments.

${ }^{1}$ N.G Konkova, researcher

${ }^{1}$ T.V. Shelenga, $\mathrm{PhD}$ in biology

${ }^{1}$ L.L. Malyshev, PhD in biology

${ }^{2}$ T.P. Rybakova, junior researcher

${ }^{2}$ M.Sh. Asfandiyarova, $\mathrm{PhD}$ in agriculture

${ }^{1}$ Federal Research Center N.I. Vavilov All-Russian Institute of Plant Genetic Resources (VIR)

42-44, Bolshaya Morskaya str., Saint-Petersburg, 190000, Russia

E-mail: ninakonkova.1@ mail.ru

${ }^{2}$ Federal Scientific Agricultural Caspian Center of the Russian Academy of Sciences,

8 Severny Kvartal, Solyonoe Zaimicshe settl., Chernoyarsky district, Astrakhan region, 416251, Russia

E-mail: rtuz@yandex.ru

Keywords: Camelina sativa, false flax, oil, protein, fatty acid composition, saturated fatty acids, unsaturated fatty acids.

We studied 315 samples of false flax (Camelina sativa (L.) Crantz) from the collection of the AllRussian Institute of Plant Genetic Resources (VIR). The study was conducted over three years in four different ecological and geographical environments. On average, for three years at all places of the study, the oil content ranged from 33.0 to $37.4 \%$, the protein content ranged from 24.7 to $29.7 \%$. More oil accumulated in the conditions of the North-Western region $37.1 \%$ and the Tambov region $-36.5 \%$. The protein 
content in the Krasnodar and Astrakhan regions was almost identical and amounted to $28.6 \%$ and $28.4 \%$. Correlation analysis showed an inverse relationship between the protein and oil contents in seeds. The correlation coefficients ranged from $r=-0.40$ to $r=-$ 0.76. Samples from the Northern Europe contained the highest oil percentage $(37.5 \%)$, the highest protein content was observed in samples of the Siberian origin $(27.8 \%)$. Analysis of the influence of temperature conditions and precipitation on the oil and protein contents in false flax seeds showed the relative independence of these traits from environmental conditions. The samples variability in terms of the regression coefficient of oil and protein contents from the sum of temperatures is $45.8 \%$ and $46.6 \%$, respectively, from the sum of precipitation $-128.9 \%$ and $184.3 \%$, which indicates a diverse response of samples to environmental conditions.

Введение. Рыжик (Camelina sativa (L.) Crantz) - масличная культура семейства капустных (Brassicaceae), широко известная как ложный лен. Самые ранние записи о рыжике в Восточной и Центральной Европе были зафиксированы в 3-м и 2-м тысячелетии до н. э. [1]. В промышленных масштабах рыжик выращивается в Западной и Восточной Сибири, где традиционно масло из семян рыжика употребляется в пищу. На небольших посевных площадях эта культура возделывается в европейской части России, в Швеции, Германии, Бельгии, Нидерландах. В настоящее время интерес к производству и, соответственно, селекции этой культуры проявляют в Испании, Франции, Австралии, США и Канаде. О возрастающем интересе к культуре свидетельствует огромное количество рецензируемых публикаций, более 335 в период с 2013 по 2016 г., причем 149 из них были опубликованы с 2015 г. [2].

Рыжик - самоопыляющееся растение, пыльца которого созревает до раскрытия цветка [3], на юге у различных видов отмечена склонность к перекрестному опылению. Изучение световой стадии популяций рыжика показало, что все его виды и подвиды являются растениями длинного дня. Из всех представителей масличных культур семейства капустных рыжик является самым устойчивым к по- ражению вредителями и болезнями, поэтому технология возделывания позволяет исключить применение большого количества гербицидов и пестицидов, что очень важно в экологическом отношении. Отмечается высокий уровень устойчивости рыжика к черной ножке (Olpidium brassicae (Woronin) P.A. Dang.), [4], к склеротиниозу (Sclerotinia sclerotiorum (Lib.) de Bary) [5], вертициллезу (Verticillium dahliae Klebahn), фузариозу (возбудители - Fusarium oxysporum Schlecht, emend. Synd. et Hans и Fusarium graminearum Schwabe) [6]. Продолжительность вегетационного периода ярового рыжика 65-90 дней, он созревает раньше других озимых и яровых (рапс, горчица, подсолнечник) культур. Урожай семян ярового рыжика $0,8-1,5$ т/га, выход масла - 0,60 т/га [7]. Средняя урожайность озимого рыжика выше, чем у яровых форм (1,9 против 1,3 т/га) [8].

Общее содержание масла в семенах составляет более $40 \%$, белка - около $30 \%$ [9; 10]. Семена рыжика характеризуются низким содержанием глюкозинолатов [11; 12], рыжиковый жмых и шрот используются при производстве комбикормов и биологических минерально-витаминных добавок $[13 ; 14]$. Определено высокое качество жирно-кислотного состава, низкое содержание насыщенных жирных кислот (менее $10 \%$ ), высокое содержание $\alpha$-линоленовой кислоты (более $30 \%$ ) и оптимальное соотношение ПНЖК n-3 линоленовой кислоты к ПНЖК n-6 линолевой кислоте (более 1), менее $3 \%$ эруковой кислоты $[15 ; 16]$. Высокая пищевая ценность масла рыжика была подтверждена на основании большого содержания токоферолов, фитостеролов и каротиноидов [17], что делает его более устойчивым к окислению.

Рыжиковое масло применяется не только для пищевых, но и для технических целей, для изготовления олифы, красок, лаков. В последнее время разрабатываются и внедряются техноло- 
гии получения биодизеля из масла рыжика $[18 ; 19 ; 20]$ и биокеросина [21].

Окружающая среда, особенно температурный и влажностный стресс, влияют на содержание масла и белка у масличных культур [22]. Цель нашей работы - выделение исходного материала для селекции рыжика по содержанию масла и белка в различных эколого-географических условиях.

Материалы и методы. Материалом для исследования послужили образцы семян ярового рыжика (Camelina sativa (L.) Crantz) из коллекции Всероссийского института генетических ресурсов растений (ВИР). Для оценки влияния условий произрастания на качество семян были проанализированы 315 образцов ярового рыжика на содержание масла и белка. Данные были опубликованы в Каталоге ВИР [9].

Исследования проводили в 2007-2009 гг. в различных эколого-географических условиях: филиал «Екатерининская опытная станция ВИР», ФЕОС (52 ${ }^{\circ} 98^{\prime}$ с.ш., $40^{\circ}$ $80^{\prime}$ в.д.), Тамбовская область; филиал «Кубанская опытная станция ВИР»,

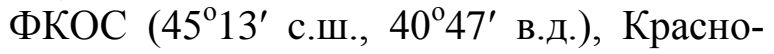
дарский край; филиал «Пушкинская опытная станция ВИР», ФПОС (59 $71^{\prime}$ с.ш., 30³8' в.д.), Ленинградская область; Прикаспийский НИИ Аридного земледе-

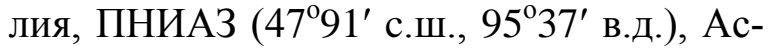
траханская область. В Астраханской области рыжик изучался два года, в 2008 и 2009 г.

Биохимические анализы проводили с использованием методов исследования растений, описанных Ермаковым [23]. Содержание масла определяли по массе сухого обезжиренного остатка с использованием аппарата Сокслета, применяя в качестве растворителя петролейный эфир $\left(\mathrm{t}\right.$ кип $\left.=40-70{ }^{\circ} \mathrm{C}\right)$ и методом инфракрасной спектрометрии на приборе «Matrix-I» (Bruker, Германия), белка - по методу Кьельдаля на автоматическом анализатоpe «KJELTECAUTO 1030 Analyzer» (Tecator, Швеция) и методом инфракрас- ной спектрометрии на приборе «MatrixI». Градуировочные спектры регистрировали в трех повторностях в стакане с дном из кварцевого стекла в режиме отражения. Спектры регистрировали в спектральном диапазоне 3500-12500 cм${ }^{-1}$. Был осуществлен тщательный подбор образцов с равномерным распределением анализируемых параметров по всему диапазону измерений. Обработку данных проводили с использованием программного обеспечения OPUS. Показатели качества градуировочных моделей по определению масличности следующие: среднеквадратичная ошибка RMSEP = $0,306 \%$, коэффициент детерминации $\mathrm{R}=$ 98,7 \%, а по определению белка - RMSEP $=0,202 \%, \mathrm{R}=96,84 \%$.

Статистическая обработка данных производилась с использованием пакетов Statistica 7.0 и Systat 10.2 и включала в себя вычисление основных параметров изменчивости (размах, среднее и ошибка среднего, коэффициент изменчивости), корреляционный анализ, дисперсионный анализ и построение уравнений линейной регрессии.

Метеоусловия в годы проведения опытов были в основном благоприятны. На рисунках 1-3 представлены климатические данные за период вегетации рыжика.

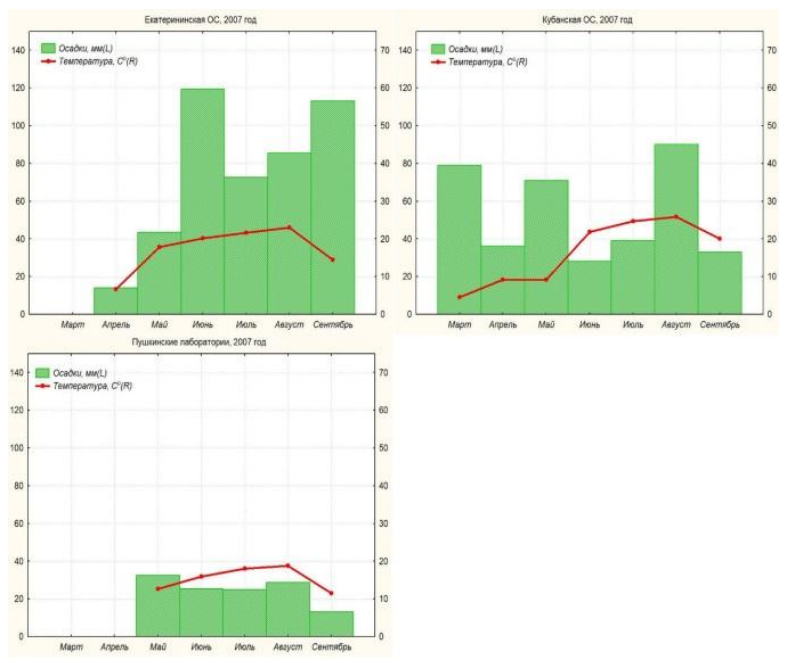

Рисунок 1 - Характеристика метеоусловий за период вегетации рыжика (2007 г.) 


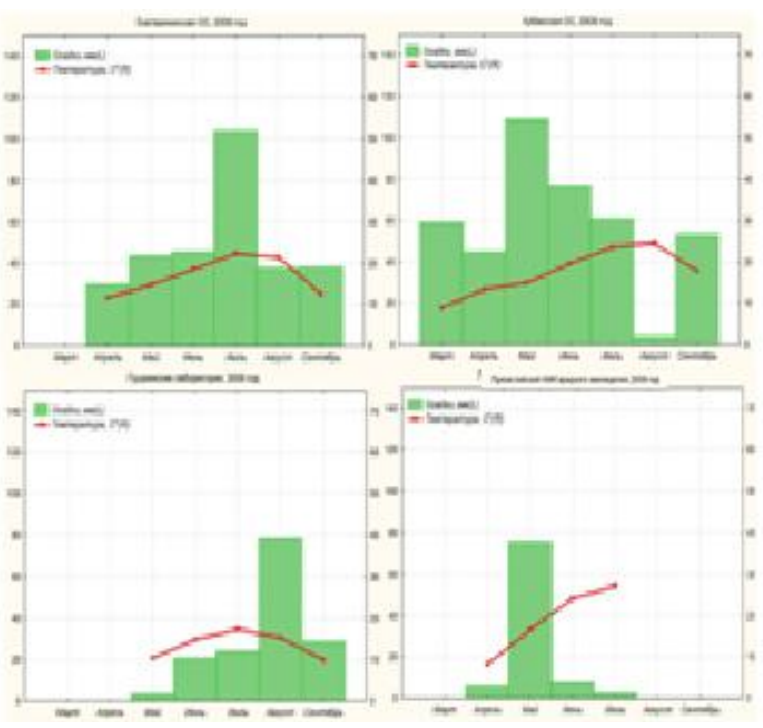

Рисунок 2 - Характеристика метеоусловий за период вегетации рыжика (2008 г.)

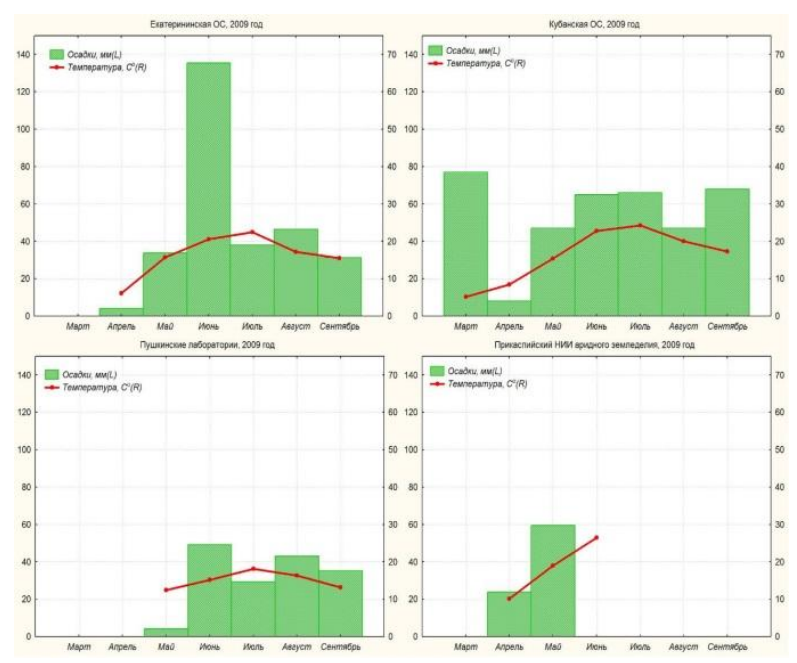

Рисунок 3 - Характеристика метеоусловий за период вегетации рыжика (2009 г.)

Результаты и обсуждение. Была изучена зависимость признака масличности и белковости семян рыжика от места, года выращивания и происхождения образцов. Среди образцов обнаружено изменение содержания масла и белка. Различия в качестве семян объяснялись главным образом совокупным воздействием климатических и почвенных условий, в которых выращивалась культура. В среднем по коллекции во всех пунктах изучения содержание масла колебалось от
33,0 до $37,4 \%$, содержание белка - от 24,7 до 29,7 \% (табл. 1 ).

Таблица 1

Изменчивость содержания масла и белка в семенах рыжнка в зависимости от места и года выращивания (2007-2009 г2.)

\begin{tabular}{|c|c|c|c|c|c|c|c|c|c|c|c|c|}
\hline \multirow[b]{2}{*}{ Год } & \multirow[b]{2}{*}{$\begin{array}{c}\text { Место изуче- } \\
\text { ния }\end{array}$} & \multicolumn{5}{|c|}{ Масло, \% } & \multicolumn{5}{|c|}{ Белок $(\mathrm{N} \times 5,5), \%$} & \multirow[b]{2}{*}{$\mathrm{r}_{\mathrm{O}-\mathrm{P}}$} \\
\hline & & Min & $\operatorname{Max}$ & $\mathrm{X}$ & $S_{x}$ & $\begin{array}{c}\mathrm{CV}, \\
\%\end{array}$ & Min & $\operatorname{Max}$ & $\mathrm{X}$ & $S_{x}$ & $\begin{array}{c}\mathrm{CV}, \\
\%\end{array}$ & \\
\hline$\overline{07}$ & ФЕOC & 3,2 & 7 & 35,97 &, 043 & 2,1 & 25,3 & 3,4 & 26,68 & 0,033 & 2,2 & 0,72 \\
\hline 2008 & & 34,7 & 41,8 & 38,59 & 0,079 & 3,6 & 16,2 & 27,7 & 24,91 & 0,062 & 4,4 & $-0,829$ \\
\hline 2009 & & & 36,3 & 34,81 & 0,102 & 2,1 & 26,7 & 28,6 & 27,53 & 0,064 & 1,6 & $-0,615$ \\
\hline \multicolumn{2}{|r|}{ Среднее } & 33,7 & 38,6 & 36,46 & 0,075 & 2,6 & 22,7 & 28,2 & 26,37 & 0,053 & 2,7 & \\
\hline 2007 & 6 & 35,1 & 43,7 & 40,09 & 0,085 & 3,7 & 20,2 & 32,9 & 23,57 & 0,068 & 5,1 & 0,655 \\
\hline & & 2,1 & 41,6 & 37,99 & 0,070 & 3,3 & 3,7 & 30,7 & 26,68 & 0,056 & 3,7 & $-0,830$ \\
\hline 2005 & & & 35,2 & 33,11 & 0,160 & 3,4 & 21,1 & 26,9 & 23,93 & 0,146 & 4,2 & $-0,88$ \\
\hline \multicolumn{2}{|r|}{ Среднее } & 36,3 & 40,2 & 37,06 & 0,105 & 3,5 & 21,7 & 30,2 & 24,73 & 0,090 & 4,3 & \\
\hline 2007 & & 28,8 & 34,2 & 32,23 & 0,050 & 2,8 & 27,6 & 30,9 & 29,32 & 0,028 & 1,7 & 0,08 \\
\hline 2008 & &, 5 & 38,5 & 36,30 & 0,056 & 2,7 & 24,9 & 29,9 & 26,61 & 0,038 & 2,5 & $-0,616$ \\
\hline 2009 & ФКОС & 30,8 & 34,4 & 27 & 1,924 & 3,7 & 28,7 & 0,6 & 29,92 & 0,071 & 1,7 & $+0,02$ \\
\hline \multicolumn{2}{|r|}{ Среднее } & 31,0 & 35,7 & $\overline{4,2}$ & 677 & 3,1 & 27,1 & 30,5 & 28,62 &, 046 & 2,0 & \\
\hline 200 & & & 35,0 & & & 4,7 & 27,6 & & 28,65 & 0,585 & 4,5 & 0,13 \\
\hline 2009 & $\overline{\Pi \mathrm{\Pi HA}}$ & 30,2 & 35,2 & 33,11 & 0,160 & 3.4 & 26,6 & 29,1 & 28,24 & 0,086 & 2,1 & $-0,656$ \\
\hline \multirow{2}{*}{\multicolumn{2}{|c|}{ Среднее }} & 30,8 & 35,1 & 32,85 & 0,418 & 4,1 & 27,1 & 29,7 & 28,44 & $0, \mathbf{3 3 8}$ & 3,3 & \\
\hline & & 3,0 & 37,4 & 35, & 319 & & 24,7 & 29,7 & 27,1 & 0,132 &,, 1 & \\
\hline
\end{tabular}

В среднем за три года в условиях Ленинградской области у образцов рыжика содержание масла колебалось от 36,3 до $40,2 \%$ и белка - от 21,7 до $30,2 \%$, в условиях Тамбовской области - от 33,7 до $38,6 \%$ и от 22,7 до $28,2 \%$, в условиях Краснодарского края - от 31,0 до 35,7 \% и от 27,1 до $30,5 \%$, в условиях ПНИАЗ в среднем за два года - от 30,8 до 35,1 \% и от 27,1 до 29,7 \% соответственно. Больше масла накапливалось в условиях северозапада, в г. Пушкин $(37,1$ \%) и в благоприятных для рыжика условиях центрально-черноземной области на Екатерининской опытной станции $(36,5 \%)$; в условиях Краснодарского края - 34,3 \% и ПНИАЗ - 32,9 \%. По содержанию масла более $37 \%$ за три года изучения во всех пунктах выделились семь образцов: к-339 из Украины (37,4 \%), к-399 из Грузии $(37,8 \%)$, к-1341 из Орловской области $(38,3 \%)$, к-4066 из Омской области $(38,7 \%)$, к-4140 из Воронежской области (38,9\%), к4145 из Киргизии $(39,5 \%)$ и к-4180 из Венгрии $(39,7$ \%). Показатели количества белка на ФКОС и в ПНИАЗ были почти на одном уровне - 28,6 и 28,4 \%, минимальные показатели по накоплению белка наблюдали на ФЕОС $(26,4 \%)$ и ФПОС $(24,7$ \%). По белку выделялись следую- 
щие образцы: к-403 (Архангельская область), к-1351 (Казанская область), к-1352 (Казанская область), к-2030 (Тверская область), к-2464 (Кировская область), к3972 (Алтай), с содержанием от 27,6 до $28,9 \%$ соответственно.

Результаты исследования показали, что количество масла увеличивается с продвижением культуры на северо-запад, условия Ленинградской области наиболее благоприятны для накопления масла в семенах рыжика [24; 26]. Прослеживается зависимость содержания масла и белка от условий года выращивания. В Ленинградской области самым благоприятным для накопления масла был 2007 г., содержание масла колебалось от 35,1 до 43,7 \%. В Тамбовской, Астраханской областях и Краснодарском крае - 2008 г., содержание масла колебалось от 34,7 до 41,8 \%; от 31,4 до $35,0 \%$ и от 35,5 до $38,5 \%$ соответственно (рис. 1-3), (табл. 1).

Содержание белка по годам изучения изменялось следующим образом: в 2009 г. наибольшее накопление белка наблюдалось в Краснодарском крае (от 28,7 до $30,6 \%$ ) и Тамбовской области (от 26,7 до $28,6 \%$ ); в 2008 г. - в Астраханской области (от 27,6 до 30,3\%); в 2007 г. - в Ленинградской области (от 20,2 до 32,9 \%) (табл. 1). Более теплые погодные условия на ФКОС и ПНИАЗ способствовали большему накоплению белка в семенах рыжика по сравнению с условиями других областей во все годы выращивания коллекции.

При изучении изменчивости показателей масличности и белковости в разных пунктах и в разные годы наблюдалась устойчивая обратная зависимость между содержанием белка и масла в семенах рыжика [25]. Коэффициенты корреляции колебались от -0,62 до -0,88 (табл. 1).

Выявлены различия в содержании масла и белка в зависимости от происхождения коллекционных образцов. Образцы из Северной Европы имели наибольший процент масла (37,7 \%), а образцы сибирского происхождения наименьший $(34,6$ \%).
Наибольшее количество белка наблюдалось у образцов из Сибири (27,8 \%), меньше - у образцов из Северной Европы $(25,6 \%)$.

Мерой влияния метеорологических условий выращивания образцов на содержание масла и белка был избран коэффициент линейной регрессии признака на соответствующий параметр среды (табл. 2, рис. 4).

Таблица 2

\section{Величина коэффициентов регрессии по образцам коллекции}

\begin{tabular}{|l|c|c|c|c|c|}
\hline \multicolumn{1}{|c|}{ Регрессия } & $\boldsymbol{X}$ & $\boldsymbol{M i n}$ & $\boldsymbol{M a x}$ & $\boldsymbol{S}_{\boldsymbol{x}}$ & $\boldsymbol{C V}$ \\
\hline Сумма температур $\rightarrow$ содержание масла & 0,015 & $-0,041$ & 0,029 & 0,0004 & 45,8 \\
\hline Сумма температур $\rightarrow$ содержание белка & $-0,011$ & $-0,041$ & 0,008 & 0,0003 & 46,6 \\
\hline Сумма осадков $\rightarrow$ содержание масла & $-0,008$ & $-0,034$ & 0,063 & 0,0006 & 128,9 \\
\hline Сумма осадков $\rightarrow$ содержание белка & 0,004 & $-0,026$ & 0,057 & 0,0004 & 184,3 \\
\hline
\end{tabular}
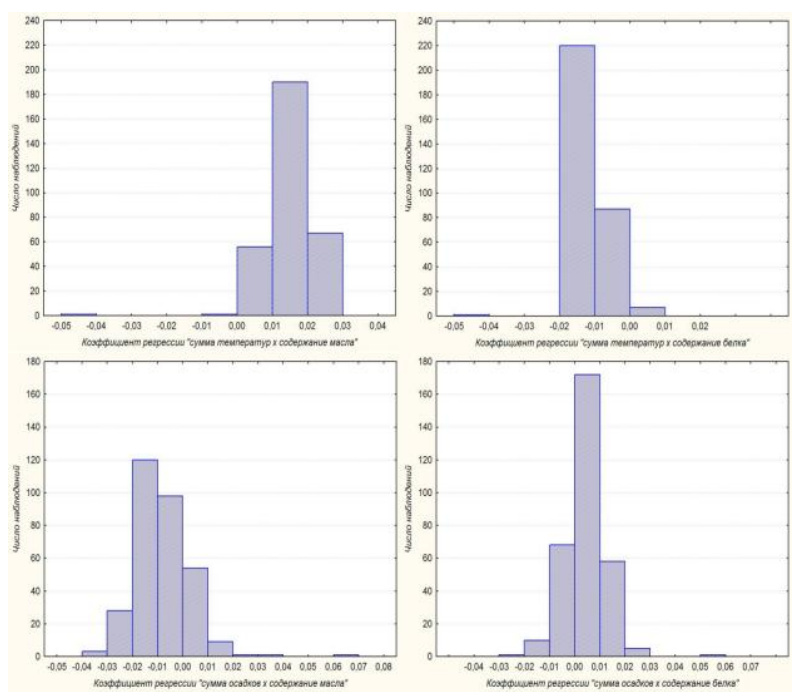

Рисунок 4 - Распределение образцов коллекции по величине коэффициента линейной регрессии $b$, масличности и содержания белка на сумму температур и сумму осадков за период вегетации

Анализ влияния температурных условий и количества осадков на содержание масла и белка в семенах рыжика показал относительную независимость данных признаков от условий среды. Коэффициент регрессии содержания масла от суммы температур за период вегетации колеблется от -0,041 до 0,029 при среднем значении 0,015 , а суммы осадков - от $-0,041$ до 0,008 при среднем -0,011. Ко- 
эффициент регрессии содержания белка от суммы температур варьирует от $-0,034$ до 0,063 при среднем значении $-0,008$, а суммы осадков - от -0,026 до 0,057 при среднем значении 0,004. Изменчивость образцов по величине коэффициента регрессии содержания масла и белка от суммы температур составляет 45,8 и 46,6 \% соответственно, от суммы осадков - 128,9 и $184,3 \%$, что свидетельствует о разнообразной реакции образцов на условия среды. В большей степени на признаки масличности и белковости влияет сумма атмосферных осадков, чем температурный фактор. Следует отметить образец к4134 (Ростовская обл.) с высокой чувствительностью к изменению температуры и недостаточному количеству осадков, что отразилось на содержании белка и масла в его семенах.

Заключение. Полученные результаты показывают, что в климатических условиях Северо-западного региона наблюдалось наибольшее содержание масла в семенах. Выделены образцы - источники высокого содержания масла и белка, которые могут быть использованы в качестве исходного материала при создании новых сортов рыжика для различных климатических зон России, что повысит эффективность селекционного процесса.

Благодарности. Работа выполнена в рамках государственного задания согласно тематическому плану ВИР по теме № 0662-2019-0001 «Коллекция масличных и прядильных культур ВИР: поддержание, изучение, расширение генетического разнообразия».

\section{Список литературы}

1. Zohary, D. and Hopf M. Domestication of plants in the Old World. - Oxford University Press, 2000. DOI: 10.1006/anbo.2001.1505.

2. Berti M., Gesch R., Eynck C., Anderson J., Cermak S. Camelina uses, genetics, genomics, production and management. Industrial // Crops and Products. - 2016. - V. 94. - P. 690-710. DOI: 10.1016/j.indcrop.2016.09.034.

3. Харитонова Л.Ф., Конькова Н.Г., Вахрушева Т.Е. Морфология и топография нектарников в цветках рыжика // Мат-лы IV Междунар. науч.-практ. конф.: Интродукция нетрадиционных и редких сельскохозяйственных растений. - 2002. - С. 178-179.

4. Seguin-Swartz G., Eynck C., Gugel R.K., Strelkov S.E., Olivier C.Y., Li J.L. [et al.]. Diseases of Camelina sativa (false flax) // Can. J. Plant Pathol. - 2009. - V. 31 (4). - P. 375-386. DOI: 10.1080/07060660909507612.

5. Purnamasari M.L., Erskine W., Croser J.S., You M.P., Barbetti M.J. Comparative reaction of Camelina sati- $v a$ to Sclerotinia sclerotiorum and Leptosphaeria maculans // Plant Disease. - 2019. - Is. 103. - Vol. 11. - P. 2884 2892. DOI: 10.1094/PDIS-03-19-0664-RE.

6. Сердюк О.А., Горлов С.Л., Трубина В.С. Болезни рыжика озимого в условиях центральной зоны Краснодарского края // Масличные культуры. Науч.-тех. бюл. ВНИИМК. - 2015. - Вып. 3 (163). - С. 91-95.

7. Туз Р.К., Асфандиярова М.Ш., Конькова Н.Г. Агробиологическое изучение коллекционных образцов ярового рыжика в аридных условиях севера Астраханской области // Мат-лы Международной науч.-практ. конф.: Эколого-мелиоративные аспекты рационального природопользования. - 2017. - С. 154-161.

8. Kurasiak-Popowska D., Tomkowiak A., Człopińska M., Bocianowski J., Weigt D., Nawracat J. Analysis of yield and genetic similarity of Polish and Ukrainian Camelina sativa genotypes // Industrial Crops and Products. - 2018. - V. 123. - P. 667-675. DOI: 10.1016/j.indcrop.2018.07.001.

9. Конькова Н.Г., Шеленга T.В. Рыжик (Camelina sativa (L.) Crantz): характеристика образцов по содержанию масла и белка в семенах // Каталог мировой коллекции ВИР. - 2019. - Вып. 886. - С. 40.

10. Marcheva M.P. Evaluation of morphology, productive potential and oil content and composition of plant genetic resources of Camelina sativa // Journal of Food and Agriculture. - 2016. - Is. 28. - V. 2. - P. 152-157. DOI: 10.9755/ejfa.2015-11-935.

11. Russo R., Galasso I., Reggiani R. Variability in Glucosinolate Content among Camelina Species // American Journal of Plant Sciences. - 2014. - V. 5. - Is. 3. - P. 294. DOI: $10.4236 /$ ajps.2014.53040.

12. Кузнецова Г., Полякова Р. Сурепица и рыжик скороспелые масличные культуры // Международный сельскохозяйственный журнал. - 2017. - № 3. - С. 4-46.

13. Cherian G., Campbell A., Parker T. Egg quality and lipid composition of eggs from hens fed Camelina sativa // J. Appl. Poult. Res. - 2009. - V. 18 (2). - P. 143-150. DOI: 10.3382/japr.2008-00070.

14. Рензяева T.B. Белковые продукты из жмыхов рапса и рыжика: получение, качество, биологическая ценность // Достижения науки и техники АПК. - 2009. № 4. - C. 70-72.

15. Ghamkar K., Croser Ja., Aryamanesh N., Campbell M., Kon kova N., Francis C. Camelina (Camelina Sativa (L.) Crantz) As an Alternative Oilseed: Molecular And Ecogeographic Analyze // Genom. - 2010. - V. 53. - No 7. P. 558-567. DOI: $10.1139 / \mathrm{G} 10-034$.

16. Конарев А.В., Лоскутов И.Г., Шеленга Т.В., Хорева В.И., Конарев А.В. Генетические ресурсы растений - неисчерпаемый источник продуктов здорового питания // Аграрная Россия. - 2019. - № 2. - С. 38-48.

17. Ratusz K., Symoniuk E., Wroniak M., Rudzińska M. Bioactive compounds, nutritional quality and oxidative stability of cold-pressed camelina (Camelina sativa L.) oils // Applied Sciences (Switzerland). - 2018. - V. 8. - Is. 12. P. 2606. DOI: 10.3390/app8122606.

18. Sainger M., Chaudhary D., Jaiwal P.K., Jaiwal A., Sainger P.A., Jaiwal R. Advances in genetic improvement of Camelina sativa for biofuel and industrial bio-products // Renewable and Sustainable Energy Reviews. - 2017. - V. 68. - P. 623-637. DOI: 10.1016/j.rser.2016.10.023.

19. Нагорнов С.А., Романщова С.В., Гаврилова В.А., Конькова Н.Г. Использование масла рыжика для производства биодизельного топлива // Наука в центральной России. - 2014. - № 4 (10). - С. 34-40.

20. Романцова С.В., Гаврилова В.А., Конькова Н.Г., Пашинин В.A. Состав и спектральные характеристики компонентов биотоплива, синтезированных из масел 
рапса, рыжика и крамбе // Вестник Тамбовского университета. - 2012. - Т. 17. - № 1. - С. 339-341.

21. Campbell M. Camelina - an alternative oil crop biokerosene // Status and Prospects. - 2017. - P. 259-275. DOI: 10.1007/978-3-662-53065-8_12.

22. Zubr J. Qualitative variation of Camelina sativa seed from different locations // Ind. Crops Prod. - 2003. - V. 17 (3). - P. 161-169. DOI: 1016/S0926-6690(02)00091-2.

23. Ермаков А. И. Методы биохимического исследования растений. - Л.: Колос, 1987. - 456 с.

24. Низова Г.К., Конькова Н.Г. Характеристика коллекции крамбе (Crambe Abyssinica Hochst.) ВИР им. Н.И. Вавилова по количеству и качеству масла // Аграрная Россия. - 2011. - № 6-2. - С. 2-6.

25. Новикова Л.Ю., Сеферова И.В., Некрасов А.Ю., Перчук И.Н., Шеленга Т.В., Самсонова М.Г., Вишнякова $M . A$ Влияние погодно-климатических условий на содержание белка и масла в семенах сои на Северном Кавказе // Вавиловский журнал генетики и селекции. 2018. - Т. 22. - № 6. - С. 708-715.

26. Низова Г.К., Конькова Н.Г. Характеристика по качеству коллекции индау // Аграрная Россия. - 2010. № 2. - С. 16-20.

\section{References}

1. Zohary, D. and Hopf M. Domestication of plants in the Old World. - Oxford University Press, 2000. DOI: 10.1006/anbo.2001.1505.

2. Berti M., Gesch R., Eynck C., Anderson J., Cermak S. Camelina uses, genetics, genomics, production and management. Industrial // Crops and Products. - 2016. - V. 94. - P. 690-710. DOI: 10.1016/j.indcrop.2016.09.034.

3. Kharitonova L.F., Kon'kova N.G., Vakhrusheva T.E. Morfologiya i topografiya nektarnikov $\mathrm{v}$ tsvetkakh ryzhika // Mat-ly IV Mezhdunar. nauch.-prakt. konf.: Introduktsiya netraditsionnykh i redkikh sel'skokhozyaystvennykh rasteniy. -2002 . - S. 178-179.

4. Seguin-Swartz G., Eynck C., Gugel R.K., Strelkov S.E., Olivier C.Y., Li J.L. [et al.]. Diseases of Camelina sati-va (false flax) // Can. J. Plant Pathol. - 2009. - V. 31 (4). - P. 375-386. DOI: 10.1080/07060660909507612.

5. Purnamasari M.L., Erskine W., Croser J.S., You M.P., Barbetti M.J. Comparative reaction of Camelina sativa to Sclerotinia sclerotiorum and Leptosphaeria maculans // Plant Disease. - 2019. - Is. 103. - Vol. 11. - P. 28842892. DOI: 10.1094/PDIS-03-19-0664-RE.

6. Serdyuk O.A., Gorlov S.L., Trubina V.S. Bolezni ryzhika ozimogo $\mathrm{v}$ usloviyakh tsentral'noy zony Krasnodarskogo kraya // Maslichnye kul'tury. Nauch.-tekh. byul. VNIIMK. - 2015. - Vyp. 3 (163). - S. 91-95.

7. Tuz R.K., Asfandiyarova M.Sh., Kon'kova N.G. Agrobiologicheskoe izuchenie kollektsionnykh obraztsov yarovogo ryzhika v aridnykh usloviyakh severa Astrakhanskoy oblasti // Mat-ly Mezhdunarodnoy nauch.-prakt. konf.: Ekologo-meliorativnye aspekty ratsional'nogo prirodopol'zovaniya. - 2017. - S. 154-161.

8. Kurasiak-Popowska D., Tomkowiak A., Człopińska M., Bocianowski J., Weigt D., Nawracał J. Analysis of yield and genetic similarity of Polish and Ukrainian Camelina sativa genotypes // Industrial Crops and Products. - 2018. - V. 123. - P. 667-675. DOI: 10.1016/j.indcrop.2018.07.001.

9. Kon'kova N.G., Shelenga T.V. Ryzhik (Camelina sativa (L.) Crantz): kharakteristika obraztsov po soderzhaniyu masla i belka v semenakh // Katalog mirovoy kollektsii VIR. - 2019. - Vyp. 886. - S. 40.

10. Marcheva M.P. Evaluation of morphology, productive potential and oil content and composition of plant genetic resources of Camelina sativa // Journal of Food and
Agriculture. - 2016. - Is. 28. - V. 2. - P. 152-157. DOI: 10.9755/ejfa.2015-11-935.

11. Russo R., Galasso I., Reggiani R. Variability in Glucosinolate Content among Camelina Species // American Journal of Plant Sciences. - 2014. - V. 5. - Is. 3. - P. 294. DOI: 10.4236/ajps.2014.53040.

12. Kuznetsova G., Polyakova R. Surepitsa i ryzhik skorospelye maslichnye kul'tury // Mezhdunarodnyy sel'skokhozyaystvennyy zhurnal. - 2017. - № 3. - S. 4-46.

13. Cherian G., Campbell A., Parker T. Egg quality and lipid composition of eggs from hens fed Camelina sativa // J. Appl. Poult. Res. - 2009. - V. 18 (2). - P. 143-150. DOI: 10.3382/japr.2008-00070.

14. Renzyaeva T.V. Belkovye produkty iz zhmykhov rapsa i ryzhika: poluchenie, kachestvo, biologicheskaya tsennost' // Dostizheniya nauki i tekhniki APK. - 2009. - № 4. - S. 70-72.

15. Ghamkar K., Croser Ja., Aryamanesh N., Campbell M., Kon`kova N., Francis C. Camelina (Camelina Sativa (L.) Crantz) As an Alternative Oilseed: Molecular And Ecogeographic Analyze // Genom. - 2010. - V. 53. - No 7. - P. 558-567. DOI: 10.1139/G10-034.

16. Konarev A.V., Loskutov I.G., Shelenga T.V., Khoreva V.I., Konarev A.V. Geneticheskie resursy rasteniy neischerpaemyy istochnik produktov zdorovogo pitaniya // Agrarnaya Rossiya. - 2019. - № 2. - S. 38-48.

17. Ratusz K., Symoniuk E., Wroniak M., Rudzińska M. Bioactive compounds, nutritional quality and oxidative stability of cold-pressed camelina (Camelina sativa L.) oils // Applied Sciences (Switzerland). - 2018. - V. 8. - Is. 12. P. 2606. DOI: $10.3390 / a p p 8122606$.

18. Sainger M., Chaudhary D., Jaiwal P.K., Jaiwal A., Sainger P.A., Jaiwal R. Advances in genetic improvement of Camelina sativa for biofuel and industrial bio-products // Renewable and Sustainable Energy Reviews. - 2017. - V. 68. - P. 623-637. DOI: 10.1016/j.rser.2016.10.023.

19. Nagornov S.A., Romantsova S.V., Gavrilova V.A., Kon'kova N.G. Ispol'zovanie masla ryzhika dlya proizvodstva biodizel'nogo topliva // Nauka v tsentral'noy Rossii. - 2014. - № 4 (10). - S. 34-40.

20. Romantsova S.V., Gavrilova V.A., Kon'kova N.G., Pashinin V.A. Sostav i spektral'nye kharakteristiki komponentov biotopliva, sintezirovannykh iz masel rapsa, ryzhika i krambe // Vestnik Tambovskogo universiteta. 2012. - T. 17. - № 1. - S. 339-341.

21. Campbell M. Camelina - an alternative oil crop biokerosene // Status and Prospects. - 2017. - P. 259-275. DOI: $10.1007 / 978-3-662-53065-8 \_12$.

22. Zubr J. Qualitative variation of Camelina sativa seed from different locations // Ind. Crops Prod. - 2003. - V. 17 (3). - P. 161-169. DOI: 1016/S0926-6690(02)00091-2.

23. Ermakov A. I. Metody biokhimicheskogo issledovaniya rasteniy. - L.: Kolos, 1987. -456 c.

24. Nizova G.K., Kon'kova N.G. Kharakteristika kollektsii krambe (Crambe Abyssinica Hochst.) VIR im. N.I. Vavilova po kolichestvu i kachestvu masla // Ag-rarnaya Rossiya. - 2011. - № 6-2. - S. 2-6.

25. Novikova L.Yu., Seferova I.V., Nekrasov A.Yu., Perchuk I.N., Shelenga T.V., Samsonova M.G., Vishnyakova M.A Vliyanie pogodno-klimaticheskikh usloviy na so-derzhanie belka i masla $\mathrm{v}$ semenakh soi na Severnom Kavkaze // Vavilovskiy zhurnal genetiki i selektsii. - 2018. - T. 22. - № 6. - S. 708-715.

26. Nizova G.K., Kon'kova N.G. Kharakteristika po kachestvu kollektsii indau // Agrarnaya Rossiya. - 2010. № 2. - S. 16-20.

Получено: 23.01.2020 Принято:27.05.2020

Received: 23.01.2020 Accepted: 27.05.2020 